\title{
U-Pb geochronology of the Lime Hill gneissic complex, Cape Breton Island, Nova Scotia
}

\author{
A.L. Sangster, P.A. Hunt and J.K. Mortensen \\ Geological Survey of Canada, 601 Booth Street, Ottawa, Ontario K1A OE8, Canada
}

Date Received May 15, 1990
Date Accepted October 22, 1990

\begin{abstract}
Low-grade metasedimentary rocks of Late Proterozoic age in the Bras d'Or Terrane of Cape Breton Island contain small areas of gneissic rocks which were previously undated. New U-Pbdata indicate that the Lime Hill gneissic complex is the product of an Early Cambrian intrusive/metamorphic event. Two intrusions at Lime Hill give similar ages which indicate that emplacement and deformation of foliated tonalitic orthogneiss were followed very quickly by intrusion of massive granitic dykes at about 540 to $545 \mathrm{Ma}$. U. $\mathrm{Pb}$ analyses of metamorphic monazite from the Lime Hill paragneiss indicate that these rocks last cooled through the closure temperature of the U-Pb system for monazite $\left(650-700^{\circ} \mathrm{C}\right)$ at about $549 \mathrm{Ma}$. All zircon fractions analyzed from the tonalitic orthogneiss and granitic dyke contain older inherited zircons which yield an apparent age range of at least 1.4 to $2.3 \mathrm{Ga}$. The presence of an inherited monazite component may suggest that the rocks have been affected by an older metamorphic event and are in fact older than the Malagawatch Formation, as suggested by published ore lead isotopic values.
\end{abstract}

Des roches métasédimentaires faiblement métamorphisées d'âge protérozoïque tardif et faisant partie de la Lanière de Bras d'Or (île du Cap Breton), renferment des îlots de roches gneissiques dont l'âge n'avait pas encore été déterminé. De nouvelles données $\mathrm{U}-\mathrm{Pb}$ indiquent que le complexe gneissique de Lime Hill est le résultat d'un épisode intrusif ou métamorphique datant du début du Cambrien. A Lime Hill, deux intrusions ont produit des âges semblables qui montrent que l'emplacement et la déformation d'un orthogneiss tonalitique furent suivis très rapidement par l'intrusion de dykes granitiques massifs, il y a environ 540 à $545 \mathrm{Ma}$. Des analyses U-Pb d'une monazite métamorphique provenant du paragneiss de Lime Hill indiquent que le demier refroidissement de ces roches en deçà de la température de clôture du système U-Pb pour la monazite, i.e. de 650 à $700^{\circ} \mathrm{C}$, eût lieu vers $549 \mathrm{Ma}$. Toutes les portions de zircons extraites de l'orthogneiss tonalitique et du dyke granitique comprennent des zircons remaniés qui donnent un âge apparent dont la gamme s'étend de 1.4 à $2.3 \mathrm{Ga}$. La présence d'une composante de monazite remaniée semble suggérer que les roches ont subi un épisode antérieur de métamorphisme, et indiquer que les roches sont en réalité plus vieilles que la Formation de Malagawatch, tel que suggéré par les valeurs publiées des isotopes du plomb du minerai.

[Traduit par le joumal]

\section{INTRODUCTION}

Several small areas of high-grade metamorphic rocks have been identified within Late Proterozoic units of central Cape Breton Island (Jamieson, 1984; Justino and Sangster, 1987; Raeside, 1989, 1990; Barr and Raeside, 1986, 1989; Raeside and Barr, in press), including the Lime Hill gneissic complex in the North Mountian inlier in central Cape Breton Island (Fig. 1). A variety of granitoid intrusions were identified during geological mapping of the Lime Hill zinc occurrence, which is hosted by marbles within the high-grade gneissic rocks at Lime Hill (Fig. 1). These include a foliated tonalitic orthogneiss stock, several varieties of foliated and/or lineated granitic to syenitic dykes and

Geological Survey of Canada Contribution No. 14690

Contribution to the Canada-Nova Scotia Mineral Development Agreement, 1984-1989. Project carried by the Mineral Resources Division, Geological Survey of Canada, Projects 860008 and 830006. unfoliated granitic to syenitic dykes (Fig. 2) (Justino and Sangster, 1987). Field relationships indicating a range of ages of intrusion, and the recognition of anomalously high-grade metamorphism led to the interpretation that the Lime Hill gneissic complex could be basement to the Late Proterozoic Malagawatch Formation northeast of the Big Brook fault (Justino and Sangster, 1987). This interpretation was supported by $\mathrm{Pb}$ isotopic analyses of galenas from the Lime Hill zinc occurrence that gave values similar to those for galenas from the marble-hosted Meat Cove zinc occurrence of Grenville age in northern Cape Breton Island (Barr et al., 1987) and similar occurrences hosted by Grenville Supergroup marble in Ontario, Quebec and New York (Sangster and Thorpe, 1988; Sangster et al., 1990).

U-Pb age studies were undertaken on rocks of the Lime Hill gneissic complex and associated intrusions to constrain the ages of intrusion and metamorphism. This paper presents the results and interpretation of $\mathrm{U}-\mathrm{Pb}$ age determinations on zircons from both foliated and unfoliated granitoid intrusions, and monazites from paragneiss in the Lime Hill gneissic complex. 


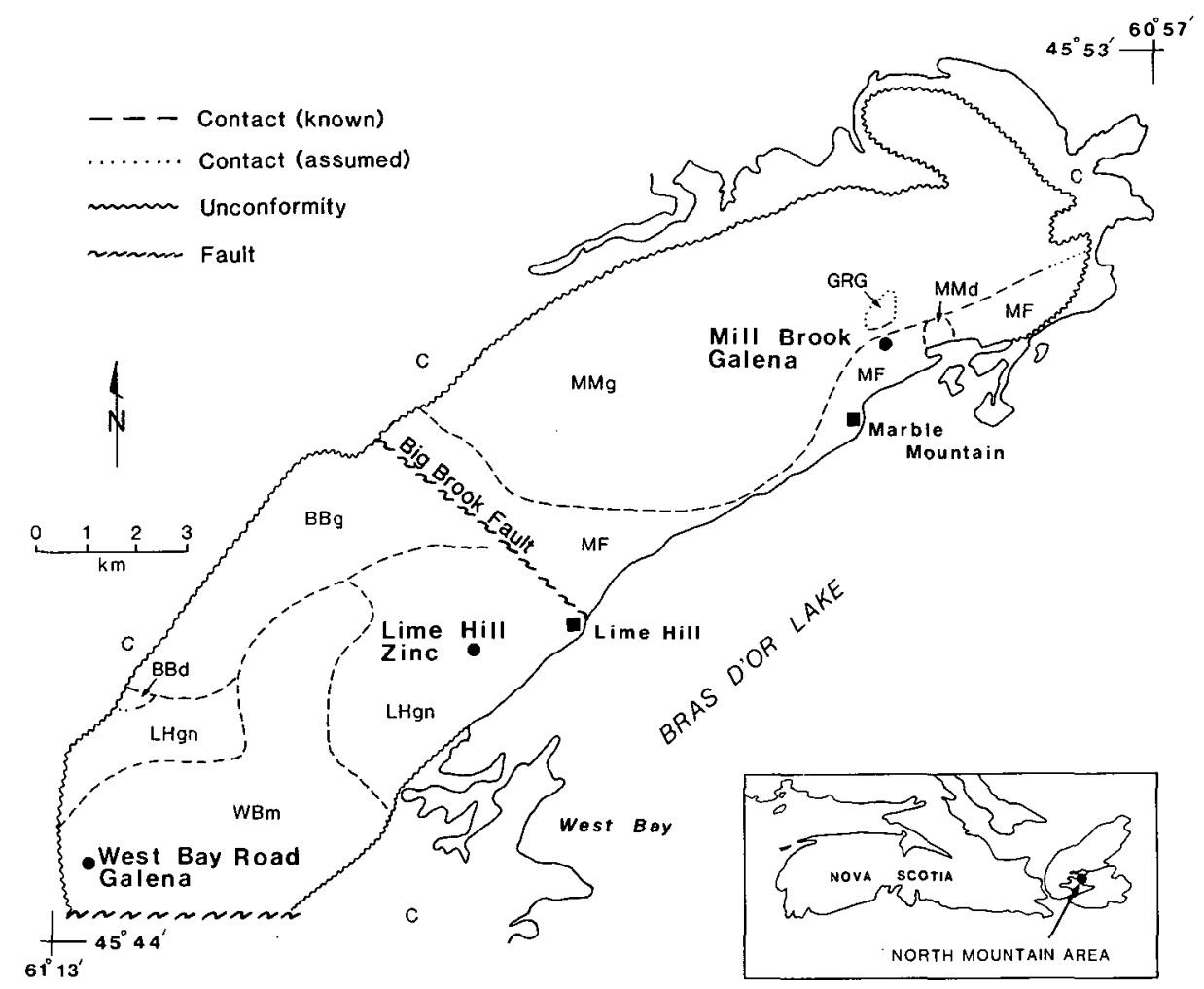

Fig. 1. Geology of the North Mountain inlier with locations of the Lime Hill Zn occurrence and the West Bay Road and Mill Brook vein Pb occurrences. Symbols: LHgn - Lime Hill gneiss; MF - Malagawatch Formation; MMg - Marble Mountain tonalite, granodiorite; MMd - Marble Mountain quartz diorite; $\mathrm{BBg}$ - Big Brook tonalite, granodionite; BBd - Big Brook diorite; WBm - West Bay monzogranite; C - Carboniferous cover rocks (modified from Sangster et al., 1990).

\section{GENERAL GEOLOGY OF NORTH MOUNTAIN}

The North Mountain inlier consists of low-grade metasedimentary rocks of the Malagawatch Formation of Late Proterozoic age, northeast of the Big Brook fault, and high-grade metamorphic rocks of the Lime Hill gneissic complex southwest of the Big Brook fault (Fig. 1) (Justino and Sangster, 1987; Sangster et al., 1990). The Malagawatch Formation and the Lime Hill gneiss, both part of the George River Group of Milligan (1970), are unconformably overlain by limestone, evaporite and coarse- to fine-grained continental clastic sedimentary rocks of Carboniferous age (Kelly, 1967).

On North Mountain, the Malagawatch Formation consists of quartzite, slate and blue to white limestone (Milligan, 1970), intruded by the Marble Mountain granodiorite of assumed Cambrian age (Cormier, 1972; Raeside, 1989). Contact metamorphic effects imposed by the granodiorite on the Malagawatch Formation consist of minor recrystallization of the limestones and moderate hornfelsing of the pelitic rocks. Small satellitic intrusions such as dykes are only locally present.

The Lime Hill gneissic complex consists of intensely deformed psammitic and pelitic gneiss, dolomite, serpentine-dolomite, and calcite marble which have been intruded by the Big Brook tonalite/granodiorite (526 $\pm 21 \mathrm{Ma}, \mathrm{K}-\mathrm{Ar}$, homblende; $\mathrm{M}$. Justino, personal communication, 1987, in Raeside, 1989) and West Bay Road monzogranite. The gneisses contain abundant foliated to massive felsic and mafic dykes (Justino and Sangster, 1987). Thermobarometric studies (Raeside, 1989, 1990) indi- cated that the rocks have undergone high-grade regional metamorphism at temperatures and pressures above $650^{\circ} \mathrm{C}$ and below $400 \mathrm{MPa}$, respectively. Raeside $(1989,1990)$ correlated the gneisses at Lime Hill with a small area of similar gneisses at Kellys Mountain in north-central Cape Breton Island that are also a product of low-pressure and high-temperature metamorphism (Jamieson, 1984). A metamorphic age of $701 \pm 66 \mathrm{Ma}$ for the Kellys Mountain Gneiss (Rb-Sr; Olszewski et al., 1981) is considered unreliable (Raeside and Barr, in press).

\section{GEOLOGY OF THE LIME HILL AREA}

The immediate area around the Lime Hill zinc occurrence is underlain by pure dolomite marble, forsterite-serpentine-dolomite marble and paragneiss, as well as a foliated tonalitic orthogneiss stock and a variety of granitic and mafic dykes and sills (Fig. 2; Justino and Sangster, 1987).

The paragneiss unit at Lime Hill is derived from both psammitic and pelitic protoliths. In general the gneiss is medium grained and consists mainly of quartz, plagioclase, brown biotite, and perthite with very minor myrmekite. Cordierite, sillimanite and garnet are commonly present. Light and dark coloured paragneiss units are interlayered and reflect variations in biotite content. Justino and Sangster (1987) subdivided the paragneiss on the basis of higher and lower biotite contents. Both units are variably migmatized and the leucosome consists dominantly of quartz with plagioclase and perthite. 


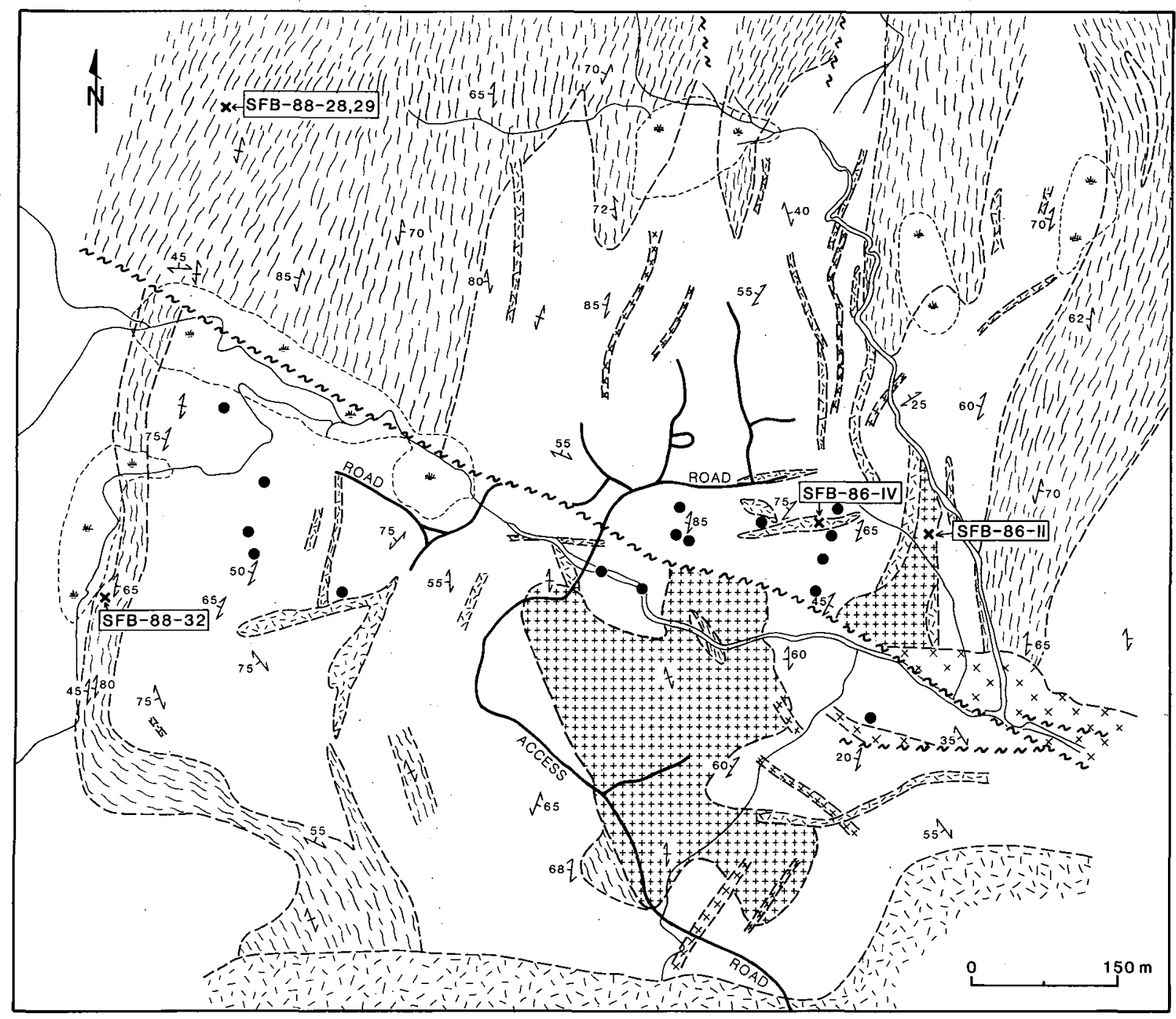

$E=0$ Biotite-quartz-feldspar gneiss



10 f strike and dip of foliation



Dolomite marble, minor salcite marble

- Zn occurrence

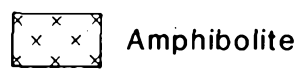

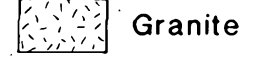

x geochronology sample location and number

Fig. 2. Geology of the Lime Hill area with sample locations. Geological base modified after Justino and Sangster (1987) and Sangster et al. (1990).

A poorly exposed tonalitic orthogneiss forms an irregularly shaped, lobate body intruding primarily dolomite marble. It is composed of plagioclase (andesine), olive to brown biotite, quartz and perthite with accessory apatite. Feldspars and biotite exhibit weak to moderate alteration to white mica and chlorite respectively. The foliation is weakly to moderately developed, streaky in character and is aligned parallel to that in the enclosing marble. The tonalitic gneiss is cut by younger granitic dykes, and has experienced potassic alteration along joints and fractures.

Granitic dykes at the Lime Hill occurrence are typically lineated to massive, fine to medium grained, well jointed, and intruded the tonalitic orthogneiss. They consist of microcline, plagioclase and quartz with a minor amount of green biotite. Texturally, the sampled dyke is dominated by poikilitic inclusions of both quartz and plagioclase in large irregular microcline grains.

Field relationships and the differing degree of strain displayed by the tonalitic orthogneiss and unfoliated granitic dykes were interpreted in the field to indicate that the tonalite is significantly older than the youngest granitic dykes, which were presumed to be Cambrian (Cormier, 1972). 


\section{U-PB GEOCHRONOLOGY}

\section{Sample descriptions}

Monazite was separated from three samples of paragneiss (Fig. 2). SFB-88-28 and SFB-88-29 are cordierite-sillimanitebearing leucosomes from quartz-plagioclase-biotite paragneiss. SFB-88-32 is biotite-rich paragneiss with thin ( $\mathrm{mm} \mathrm{scale}$ ) quartzfeldspar leucosomes.

Zircons were separated from one sample each of tonalitic orthogneiss and massive granitic dyke from the vicinity of the east zinc occurrence (Fig. 2). Sample SFB-86-II, a weakly foliated tonalitic orthogneiss, was collected from a dyke-like protrusion in the northern part of the main tonalitic orthogneiss stock. Sample SFB-86-IV, a massive fine-grained granite, is from a dyke exposed in the northwestern comer of the \#9 trench (Sangster et al., 1990). Whole-rock and trace-element analyses of the tonalitic orthogneiss and granitic dyke samples are given in Table 1.

\section{Analytical methods}

U- $\mathrm{Pb}$ analytical methods follow those outlined in Parrish $e t$ al. (1987). Sample preparation included strong air abrasion of all zircon fractions (Krogh, 1982), dissolution in microcapsules (Parrish, 1987), use of a mixed ${ }^{205} \mathrm{~Pb}^{233} \mathrm{U}_{-}{ }^{235} \mathrm{U}$ isotopic tracer (Parrish and Krogh, 1987), multicollector mass spectrometry (Roddick et al., 1987), and assessment of errors by numerical error propagation (Roddick, 1987). For the zircon analyses, the uranium blank ranged from 0.001 to $0.002 \mathrm{ng}$ and the $\mathrm{Pb}$ blank ranged from 0.024 to $0.016 \mathrm{ng}$. For the monazite analyses the $U$ blank was $0.01 \mathrm{ng}$ and the $\mathrm{Pb}$ blank was $0.016 \mathrm{ng}$. Analytical results are presented in Table 2.

\section{ANALYTICAL RESULTS}

\section{Tonalitic orthogneiss (SFB-86-II)}

Zircons separated from the tonalitic orthogneiss are euhedral and prismatic, with sharp to slightly rounded terminations. The "length:breadth" ratio is 3:1, and grains are very clear with only rare clear inclusions. The zircons show no evidence of cores or of mixed populations.

Five zircon fractions were analyzed (Table 2). Four of the five are colinear and plot near the lower intercept of a discordia line (Fig. 3). A modified York regression (see Parrish et al., 1987) through the four points yields an upper intercept of $1.7 \pm 0.1 \mathrm{Ga}$, a lower intercept of $539 \pm 1 \mathrm{Ma}$, and a MSWD of 0.3 . The results are interpreted to reflect a zircon population that is a physical mixture of newly grown grains and older inherited "cryptic" cores that were not detected visually. Fraction $\mathrm{C}$ lies below this discordia line, likely indicating both the presence of an inherited component and surface-correlated post-crystallization $\mathrm{Pb}$-loss effects that were not completely removed by air abrasion. The lower intercept age (539 $\pm 1 \mathrm{Ma}$ ) represents a minimum crystallization age for the tonalitic orthogneiss, and the maximum possible age is unlikely to be significantly older than the youngest
Table 1. Chemical analyses* of samples of Lime Hill intrusions dated in this study.

\begin{tabular}{lcc}
\hline & $\begin{array}{c}\text { SBF-86-II } \\
\text { TONALITE } \\
\text { GNEISS }\end{array}$ & $\begin{array}{c}\text { SFB-86-IV } \\
\text { GRANITIC } \\
\text { DYKE }\end{array}$ \\
\hline $\mathrm{SiO}_{2}$ & 65.40 & 74.40 \\
$\mathrm{TiO}_{2}$ & 0.50 & 0.21 \\
$\mathrm{Al}_{2} \mathrm{O}_{3}$ & 16.70 & 13.90 \\
$\mathrm{Fe}_{2} \mathrm{O}_{3}{ }^{\mathrm{t}}$ & 4.21 & 1.45 \\
$\mathrm{MnO}$ & 0.13 & 0.05 \\
$\mathrm{MgO}$ & 1.89 & 0.68 \\
$\mathrm{CaO}$ & 4.96 & 2.32 \\
$\mathrm{Na}{ }_{2} \mathrm{O}$ & 3.58 & 3.76 \\
$\mathrm{~K}_{2} \mathrm{O}$ & 1.13 & 2.68 \\
$\mathrm{P} \mathrm{O}_{5}$ & 0.13 & 0.07 \\
$\mathrm{LOI}$ & 1.70 & 0.54 \\
$\mathrm{TOTAL}$ & 100.33 & 100.06 \\
& & \\
$\mathrm{Sr}$ & 380 & 400 \\
$\mathrm{Ba}$ & 230 & 610 \\
$\mathrm{Rb}$ & 50 & 110 \\
$\mathrm{Cr}$ & 20 & 10 \\
$\mathrm{Zr}$ & 150 & 70 \\
$\mathrm{Y}$ & 40 & 20 \\
$\mathrm{~V}$ & 0.5 & 0.5 \\
$\mathrm{Nb}$ & 20 & 10 \\
& & \\
\hline
\end{tabular}

\footnotetext{
*Major-element (in weight \%) and trace-element (in ppm) analyses by $\mathrm{X}$-ray fluorescence at Assay Laboratories Limited, Toronto.
}

${ }^{207} \mathrm{~Pb} /{ }^{206} \mathrm{~Pb}$ age (Fraction $\mathrm{B}-550 \pm 2 \mathrm{Ma}$ ). We therefore consider the best estimate of crystallization age for the tonalitic orthogneiss to be $545 \pm 7 \mathrm{Ma}$. The tonalitic orthogneiss has incorporated older zircons with an average age of $1.7 \mathrm{Ga}$.

\section{Granitic dyke (SFB-86-IV)}

Zircons separated from the granitic dyke are euhedral and prismatic with well defined terminations. The grains are clear with minor cracks and clear inclusions. No cores could be detected visually.

Five multiple grain fractions of zircon were analyzed (Table 2). As with the previous sample, these data form a roughly linear array suggestive of mixed igneous and inherited zircons (Fig. 4). There is, however, considerable scatter in the data. The least discordant analysis (fraction A) is thought to consist mainly of newly grown igneous zircons. Two point discordia lines through this point and the more discordant points (fractions $\mathrm{C}$ and $\mathrm{E}$ ) can be used to constrain both the possible emplacement age of the dyke, and the range of ages of the inherited zircon component. Lower intercept ages calculated in this way range from 540 to 545 $\mathrm{Ma}$, and upper intercept ages range from 1.4 to $2.3 \mathrm{Ga}$. These results indicate that a minimum emplacement age for the dyke is 
Table 2. U-Pb analytical data for zircon and monazite age determination.

\begin{tabular}{|c|c|c|c|c|c|c|c|c|c|c|c|}
\hline $\begin{array}{l}\text { Fraction } \\
\text { size }^{\mathrm{a}}\end{array}$ & $\begin{array}{l}\text { Wt. } \\
\text { (mg) }\end{array}$ & $\underset{(\mathrm{ppm})}{\mathrm{U}}$ & $\begin{array}{c}\mathrm{Pb}^{*} \\
(\mathrm{ppm})\end{array}$ & $\frac{206 \mathrm{~Pb}}{204 \mathrm{~Pb}}$ & $\begin{array}{l}\mathrm{Pb}^{\mathrm{b}} \\
(\mathrm{pg})\end{array}$ & $\frac{208 \mathrm{~Pb}}{(\%)}$ & $\begin{array}{l}{ }^{206} \mathrm{~Pb} \\
238 \mathrm{U}\end{array}$ & $\frac{207 \mathrm{~Pb}}{235 \mathrm{U}}$ & $\begin{array}{l}\text { Corr. } \\
\text { Coeff. }\end{array}$ & $\frac{207 \mathrm{~Pb}}{206 \mathrm{~Pb}}$ & $\begin{array}{c}{ }^{207} \mathrm{~Pb} /{ }^{206} \mathrm{~Pb} \text { age } \\
(\mathrm{Ma})\end{array}$ \\
\hline \multicolumn{12}{|c|}{ SFB-86-II. Tonalite Orthogneiss } \\
\hline A $-62 \mathrm{Abr}$ & .018 & 442 & 39 & 974 & 46 & 10.0 & $.08773 \pm .12 \%$ & $.7080 \pm .18 \%$ & .7377 & $.05853 \pm .12 \%$ & $549.6 \pm 5.2$ \\
\hline B $-74+62 \mathrm{Abr}$ & .031 & 354 & 32 & 2563 & 24 & 10.4 & $.08765 \pm .09 \%$ & $.7075 \pm .11 \%$ & .9030 & $.05854 \pm .05 \%$ & $550.2 \pm 2.0$ \\
\hline $\mathrm{C}-105+74 \mathrm{Abr}$ & .071 & 532 & 47 & 5324 & 39 & 10.6 & $.08709 \pm .09 \%$ & $.7141 \pm .10 \%$ & .9103 & $.05947 \pm .04 \%$ & $584.3 \pm 1.8$ \\
\hline $\mathrm{D}-74+62 \mathrm{Abr}$ & .061 & 559 & 50 & 8956 & 21 & 10.1 & $.08812 \pm .09 \%$ & $.7155 \pm .10 \%$ & .9571 & $.05889 \pm .03 \%$ & $563.0 \pm 1.3$ \\
\hline E $-74+62 \mathrm{Abr}$ & .046 & 617 & 56 & 3445 & 46 & 10.2 & $.08935 \pm .09 \%$ & $.7358 \pm .11 \%$ & .9246 & $.05972 \pm .04 \%$ & $593.6 \pm 1.8$ \\
\hline \multicolumn{12}{|c|}{ SFB-86-IV. Granitic dyke } \\
\hline $\mathrm{A}+74 \mathrm{Abr}$ & .032 & 615 & 59 & 4362 & 25 & 15.3 & $.08873 \pm .10 \%$ & $.7215 \pm .11 \%$ & .9471 & $.05898 \pm .04 \%$ & $566.4 \pm 1.6$ \\
\hline B -74 Abr Short Thick & .036 & 515 & 51 & 2235 & 50 & 9.9 & $.09711 \pm .12 \%$ & $.8707 \pm .14 \%$ & .9103 & $.06503 \pm .06 \%$ & $.1 \pm 2.4$ \\
\hline C -74 Abr Tips & .028 & 635 & 61 & 3277 & 32 & 12.4 & $.09202 \pm .09 \%$ & $.7992 \pm .10 \%$ & .9373 & $.06299 \pm .04 \%$ & $707.9 \pm 1.6$ \\
\hline$A \mathrm{hrI} O \mathrm{O}$ & .050 & 695 & 67 & 5160 & 30 & 12.9 & $.09234 \pm .09 \%$ & $.7825 \pm .11 \%$ & .9518 & $.06146 \pm .03 \%$ & $655.4 \pm 1.4$ \\
\hline E -74 Abr & .013 & 874 & 99 & 4763 & 17 & 9.9 & $.11056 \pm .09 \%$ & $1.0354 \pm .10 \%$ & .9422 & $.06792 \pm .04 \%$ & $866.0 \pm 1.5$ \\
\hline \multicolumn{12}{|c|}{ SFB-88-28. Lime Hill paragneiss } \\
\hline 28A (monazite) & .007 & 1622 & 1165 & 3133 & 21 & 88.6 & $.08890 \pm .10 \%$ & $.7198 \pm$ & .9408 & $.05872 \pm .04 \%$ & $556.8 \pm 1.7$ \\
\hline $28 \mathrm{~B}$ (monazite) & .017 & 1562 & 1082 & 4872 & 30 & 88.3 & $.08829 \pm .10 \%$ & $.7121 \pm .11 \%$ & .9371 & $.05850 \pm .04 \%$ & $548.5 \pm 1.7$ \\
\hline \multicolumn{12}{|c|}{ SFB-88-29. Lime Hill paragneiss } \\
\hline 29A (monazite) & .003 & 1775 & 1457 & 1520 & 22 & 90.1 & $.08895 \pm .11 \%$ & $.7176 \pm .13 \%$ & .9171 & $.05851 \pm .06 \%$ & 548.8 \\
\hline 29B (monazite) & .066 & 2197 & 1337 & 3181 & 23 & 86.6 & $.08902 \pm .13 \%$ & $.7240 \pm .13 \%$ & .8402 & $.05899 \pm .07 \%$ & $566.6 \pm 3.2$ \\
\hline \multicolumn{12}{|c|}{ SFB-88-32. Lime Hill paragneiss } \\
\hline $32 \mathrm{~A}$ (monazite) & .007 & 419 & 562 & 803 & 20 & 93.9 & $.08968 \pm .16 \%$ & $.7308 \pm .19 \%$ & .8604 & $.05910 \pm .10 \%$ & $570.8 \pm 4.2$ \\
\hline 32B (monazite) & .007 & 945 & 1108 & 1184 & 33 & 92.9 & $.09113 \pm .31 \%$ & $.7663 \pm .34 \%$ & .6633 & $.06098 \pm .27 \%$ & $638.7 \pm 11.5$ \\
\hline
\end{tabular}

Errors are 1 std. error of mean in \% except ${ }^{207} \mathrm{~Pb} /{ }^{206} \mathrm{~Pb}$ age errors which are 2 std. errors in Ma.

aSizes (-74+62 refer to length aspect of zircons in microns, i.e., through 74 micron sieve but not the 62 micron sieve).

abr - Abraded.

bTotal common $\mathrm{Pb}$ in analysis in picograms.

${ }^{\circ}$ Correlation coefficient of errors in ${ }^{206} \mathrm{~Pb} /{ }^{38} \mathrm{U}$ and ${ }^{207} \mathrm{~Pb} / 235 \mathrm{U}$.

$\mathrm{Pb}^{*}$ - Radiogenic $\mathrm{Pb}$. 


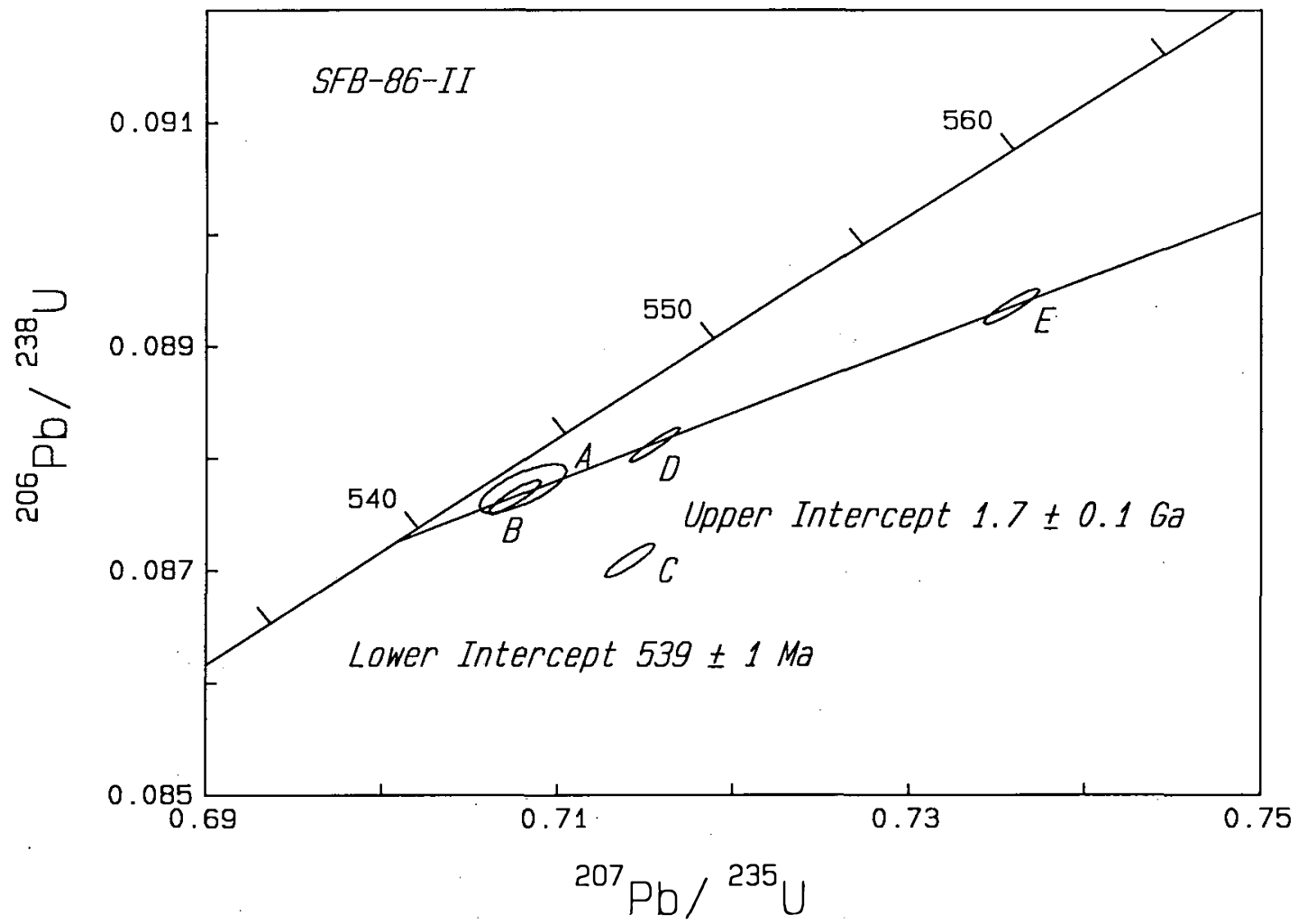

Fig. 3. U-Pb concordia diagram of zircon analyses from the tonalitic orthogneiss (SFB-86-II).



Fig. 4. U-Pb concordia diagram of zircon analyses from the granitic dyke (SFB-86-IV). 


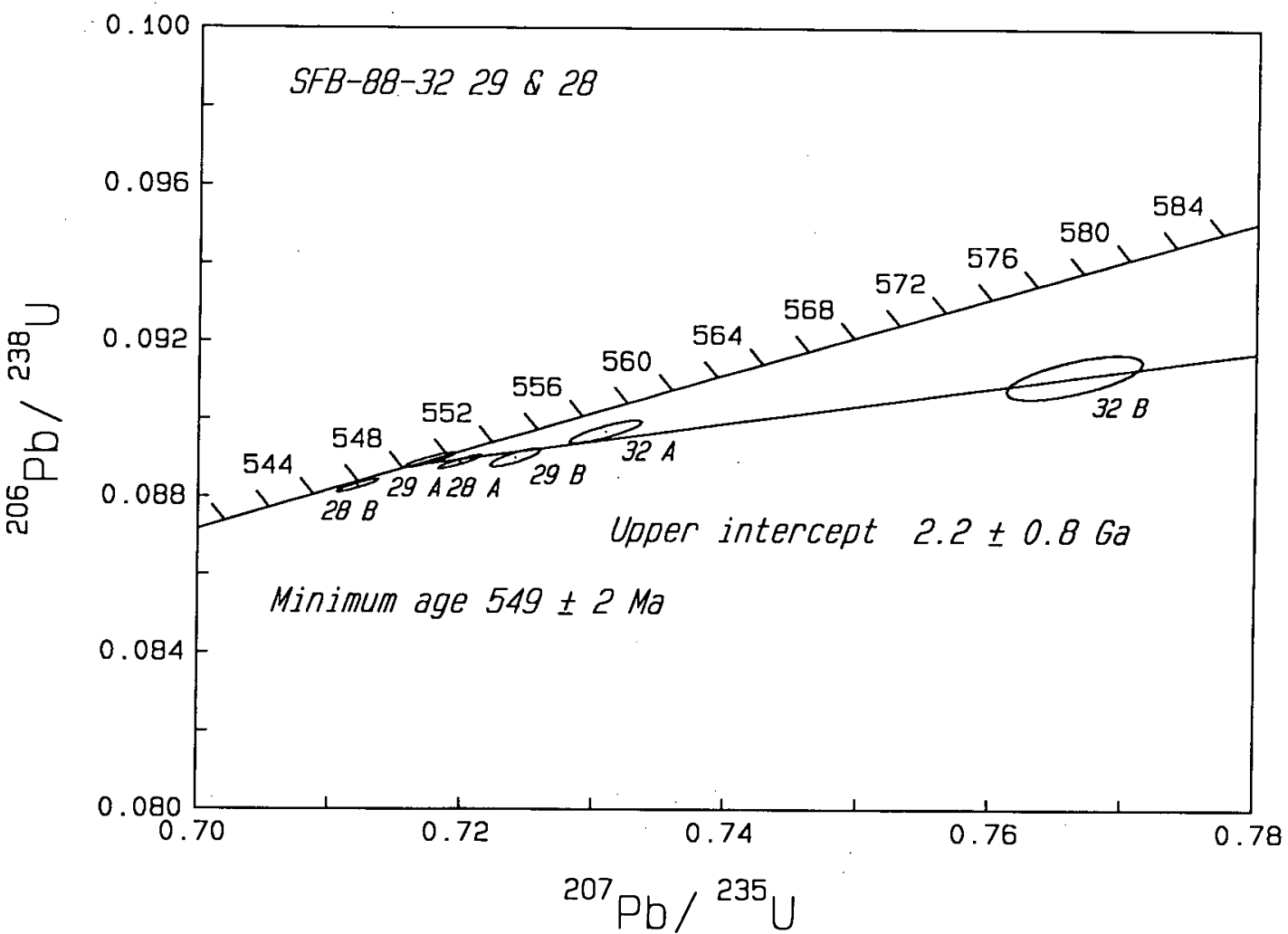

Fig. 5. U-Pb concordia diagram of monazite analyses from biotite-quartz-feldspar paragneiss (SFB-88-28, -29, and -32).

$540 \pm 1 \mathrm{Ma}$ (youngest lower intercept age). The age of dyke emplacement is unlikely to be older than the ${ }^{207 \mathrm{~Pb} / 006 \mathrm{~Pb}}$ age of the most concordant fraction (566 $\pm 2 \mathrm{Ma}$ ); however, the field relationships described above indicate that the tonalitic orthogneiss was intruded by the granite dyke. We therefore estimate the emplacement age for the granitic dyke to be about 540 to $545 \mathrm{Ma}$. The inherited zircon component gives a minimum age range of 1.4 to $2.3 \mathrm{Ga}$.

\section{Paragneisses (SFB-88-32, -29, and -28)}

Metamorphic monazite was separated from three samples of metapelitic Lime Hill paragneiss that was intruded by the tonalitic orthogneiss and granitic dyke units.

Two fractions of monazite were analyzed from each of the three paragneiss samples (Table 2). The monazite crystals are anhedral, rounded and pale yellow in colour, generally clear with no visible evidence of zoning or cores. One of the six fractions (29A) is concordant and yields a ${ }^{207} \mathrm{~Pb} /{ }^{206} \mathrm{~Pb}$ age of $548 \pm 8 \mathrm{Ma}$ (Fig. 5, Table 2). Another fraction (28B) falls slightly below concordia, but yields an identical ${ }^{207} \mathrm{~Pb} /{ }^{206} \mathrm{~Pb}$ age to sample $29 \mathrm{~A}$, probably reflecting minor post-crystallization $\mathrm{Pb}$ loss. The other four monazite fractions are more discordant, and yield ${ }^{201} \mathrm{~Pb} /{ }^{206} \mathrm{~Pb}$ ages which range from 557 to $639 \mathrm{Ma}$ (Fig. 5).

The concordant monazite age gives a minimum crystallization age for metamorphic monazite in the Lime Hill paragneiss. The true age of monazite crystallization may be slightly older than this, if excess ${ }^{206} \mathrm{~Pb}$ was originally present in the grains (Schärer, 1984; Parrish, 1988).
The data for fraction $29 \mathrm{~A}$ and the four fractions that yield older ${ }^{201} \mathrm{~Pb} /{ }^{206} \mathrm{~Pb}$ ages form an array similar to that defined by the zircon analyses from the tonalitic orthogneiss and granitic dyke. It therefore appears likely that the monazite data similarly represent a mixed population between a newly grown metamorphic monazite component of about $550 \mathrm{Ma}$, and an older inherited monazite component. The calculated upper intercept for the monazite data array (excluding fraction $28 \mathrm{~B}$ ) is $2.2 \pm 0.8 \mathrm{Ga}$ (Fig. $5)$. Although the calculated upper intercept age is within the range of ages for the inherited zircon component in the tonalitic orthogneiss and granitic dyke, the uncertainties introduced by possible excess ${ }^{206} \mathrm{~Pb}$ in some or all of the monazite analyses, together with post-crystallization $\mathrm{Pb}$ loss effects, and the possibility of a range of ages for the inherited monazite component, make this upper intercept age of doubtful value.

\section{DISCUSSION}

The complex U-Pb systematics displayed by zircons from the tonalitic orthogneiss and granitic dyke preclude assigning precise ages of crystallization to these intrusions. These data indicate, however, that the two bodies are very similar in age, and were both intruded at about 540 to $550 \mathrm{Ma}$. The tonalitic orthogneiss was deformed along with the host paragneisses prior to intrusion of the granite dyke. Thus at least the latest phase of deformation that affected the Lime Hill area must have occurred at about $545 \mathrm{Ma}$. The age of $549 \mathrm{Ma}$ for metamorphic monazite in the host paragneisses gives the time of last cooling through the closure temperature of the $\mathrm{U}-\mathrm{Pb}$ system in monazite at about $650^{\circ}$ 